\title{
THE ENTRANCE OF FOREST RESERVES INTO FOREST POLICY IN BRITISH COLUMBIA.
}

\section{F. D. Mulholland}

"We have been talking about forestry for forty years in this country, and as yet we have no definitely stated or legislatively enacted forest policy on the part of the Dominion Government, or that of any Province, based on the fundamental essential of continuous production." That is the opening sentence of an article recently published by Canada's foremost forester, Dr. Howe, of Toronto.

Dr. Howe says that our lack of forest policy is due chiefly to three reasons:- to the idea that forests must be cleared away to make room for farms; to the idea that our standing timber is inexhaustible; and to the fact that foresters have had to devote most of their attention and energy to fire protection. If we agree with Dr. Howe's accusation, another reason may be added for the absence in British Columbia in the past of an active policy based on continuous production, namely; the pressure of economic facts. We have so much forest for a very sparse population, which realizes quite well that the timber is not unlimited, but which has to make a living out of exporting it. Only the higher grades can be sold at a profit, so waste is unavoidable, and the distribution of an annual cut that would be most desirable for sustained and regulated forest production in definite localities, has not, so far, been economically possible. Export to distant countries has demanded cheap timber, the country has needed revenue, and timber has had to be disposed of without much consideration for what would follow it after it was cut. Technically, it might be said that the cut was regulated financially by the force of circumstances rather than by the applied science of forestry. The business of providing continuous supplies of wood has so far been carried on successfully.

Section 29 of our "Forest Act" provides for the perpetual growing of timber in Forest Reserves and defines our Forest Reserve policy. 6,500,000 acres have already been dedicated to continuous production and this acreage is being increased each year.

The fact that forest policy develops slowly in a new country does not necessarily imply that some sinister influence is abroad, or that a later policy and an earlier one cannot both be right for the times in which they exist. British Columbia is still a new country and our forest policy, therefore, has not yet reached full development; nor can it until means of transportation and markets expand far beyond anything we imagine today. There were predictions of timber shortage in Europe two centuries ago. The famine was avoided by economy, scientific management and, last but not least, by the invention and development of transportation by railways.

Now conditions in B. C. seem to indicate a need for revision of the 
plan. The kind of forestry that was suited to conditions twenty years ago, or even ten years ago, is not necessarily the kind that suits the needs of today. Since the science of forestry presupposes that the object of forestry is continuous supply of wood, its application hinges on the regulation of the annual cut. We do not need much science to regulate an annual cut which lack of market restricts to only one two-hundredth part of the visible supply of standing timber, which is what it was ten years ago. In an exporting country like British Columbia, the amount and kind of wood which can be produced annually is limited, not only by the extent of forest land available and the sustained volume it can be made to produce, but also by the markets that can be reached and the local industries that can be maintained in the process.

Now, however, the annual cut is twice what it was ten years ago and very unevenly distributed throughout the Province. It is an axiom of forestry science that the business of producing continuously the maximum values in wood can only be carried on successfully in forests which have been permanently dedicated to that business. In our operations outside such permanent forests, we can hardly practice anything but a temporary appearance of forestry, however good silviculture and protection may be provided. Obviously, a maximum sustained production cannot be achieved if it is uncertain whether the forest being logged today will be allowed to produce another crop of timber or not. Nor is it undue pessimism to doubt if vast, vaguely known areas of lodgepole pine on the mountain ranges of the Interior will grow up satisfactorily to replace on the market fifty years hence the high grade fir which is being cut in the coast forests today.

These things were taken into consideration twenty years ago, when the first forest policy in British Columbia was being formulated. Although the dedication of forest areas to perpetual production was provided for in the first "Forest Act," the conditions I have mentioned did not allow an active policy of reservation to be carried out until a few years ago. Now a definite programme of $1,000,000$ acres of new Forests a year has been adopted. During the last three years an average of over 800,000 acres per annum has been reserved. We are making complete forest surveys of the reserved Forests as fast as the new Forests are created.

This policy is certain to make radical changes in forest administration. Its execution is already costing considerable sums of money and the Forest Service will be expected to show results. It will not disappoint those expectations. The effects are already becoming evident. We are beginning to learn that there is a definite limit to the amount of timber which can be cut in certain localities without creating conditions which will cause a local shortage at some time in the future. We are obtaining information from our surveys on the actual rate of growth of each type in each Forest which enables us to regulate the cut so as to avoid such a shortage if it is desirable 
to do so. It is not expected that so called normal forests will result, but good management will gradually provide that the necessary volume of merchantable wood is available each year in each Forest for the industries concerned. Normal density and normal yield are fictions of the imagination; they are of little interest to the practical forester except as an ideal; no one knows, ever did know or ever will know what they are.

Sustained yield is not always a possibility for a limited area of forest. Sometimes though possible it is not good economics and, therefore, not sound forestry. From a forest largely composed of over-mature, decadent timber, with an immediate market value, immediate cutting may give a greater return financially than salvage from the dying trees saved for fifty years in the interests of sustained yield, even after discounting the probable economic loss through the future closing down of a local industry for lack of timber. On the other hand, to a country owning its own forests, a sustained yield with a stabilized industry and steady revenue may be a matter of greater concern than the amount of capital that is tied up in its merchantable timber, or than the rate of interest it earns. Somewhere between the financial, silvicultural and sustained yields, a decision must be made for preliminary regulation of the cut of each Forest for the next decade or so. This decision is being made following the survey of each Forest. At first it is better to be conservative and cut less than might appear possible if all the factors which will affect the future of the Forest should be beneficial. By keeping the cut low we are not at present closing any mills nor keeping anyone out of the lumber industry; there is plenty of alienated timber on the market. By way of illustration, in the Inkaneep Forest there are 271,000,000 feet of mature merchantable timber. Financially, this should all be cut as soon as a purchaser can be found; silviculturally, most of it could be cut at once by selective logging, leaving sufficient seed trees; but there is a great scarcity of younger age classes in these natural selection types, and with maturity at the age of 200 , the periods between logging will be long. All young even-aged stands in the Forest are lodgepole pine of a very poor quality and likely to be beetle-killed before any use can be made of them. To keep the Forest productive, it will not be safe to cut more than the sustained yield of the uneven-aged types. On four coast island Forests there are over 1,000,000,000 feet of timber ripe for the saw, $80 \%$ licensed. There are no young stands older than 30 years and few younger. Because of the absence of middle age classes, the sustained annual yield would only be $14,000,000$. Since this cut is already being greatly exceeded by the licencees, whom we cannot control, it seems desirable that not a stick of unalienated Crown timber should be sold.

We have been making timber sales to any applicant who could put up the money, if he agreed to take a complete unit and log clean. This procedure is already obsolete within Provincial Forests in that consideration is now given first to the effect of the proposed operation on the estimated yield 
of the Forest and on the utilization of the Forest as a working circle. This policy of regulation already has the effect of creating a demand for more intensive technical supervision in the Forests.

The effect of the Forest Reserve policy is being felt also in protection. We are beginning to realize that some areas are worth much more expenditure than others. Some are not worth any at all as forest land. To prophesy a little, as forest lands are classified and non-productive areas mapped, there will be a gradual withdrawal of fire protection from those areas which will not repay its cost. The protection of rural communities, sub-alpine irrigation watersheds, settlers' improvements and prospectors' cabins from fires in agricultural, scrub and barren lands, will become the responsibility of the interests benefited thereby, and the cost charged to municipalities, rural districts, parks or departments concerned with public recreation or tourist attraction, rather than be regarded as a necessary expense of forest administration. For a while the curious phenomenon may be seen of foresters forced by public opinion, against their better judgment, to spend forest revenue on the protection of lands of no forest value, because the public conscience has learned from the foresters' own publicity that any fire out-of-doors is a forest fire. In time, however, when all the Forests are reserved, the Forest Service will not be a general fire-brigade but will function only in the Forests for which it is responsible.

Another effect of the Forest Reserves is appearing in land policy. To make reserves necessitates examination and classification of the land. In doing this we are finding that a great deal of past settlement has suffered from lack of guidance, many an abandoned pre-emption is going permanently into the new Forests, and we are oiling the machinery for exchange of agricultural land outside the boundaries for forest land within, which machinery was provided with the reserve legislation, but never yet used. In addition, our boundary surveys are providing the Government Agents with a real basis, in reliable land classification maps, for the guidance of future settlement in the localities we cover. Within the Forests the necessity for ensuring, by more careful field examination, that leases and other uses do not militate against the purpose for which the Forest was created, is gradually bringing about less waste of time, money and natural resources by applicants with ill-considered plans for the use of the land.

We have been asked to what purpose we would reserve forest lands on which the timber has been nearly all alienated, especially on Vancouver Island and the coast. Through lack of control of the standing timber, instead of regulation on a sustained yield basis, there will be a financial yield dictated by market conditions. Nevertheless, it would surely be illogical to leave to the last the most productive part of our forest land, while dedicating to perpetual forest the less valuable. When such an area has been set apart for permanent timber production, we can at least require the operators to take 
any reasonable action that may tend to provide for natural reforestation. British Columbia lent the licencees a productive forest with permission only to harvest the mature crop-it is not unreasonable to ask them to return it still in a productive state. Apart from that, the mere recording and mapping of such areas as reserves will help materially to provide the comprehensible, live inventory of forest resources which is indispensable for the formulation and execution of a sane forest policy.

In Forest Reserves lies the future of B. C. forestry; and in them only can provision be made with any chance of success against a serious timber shortage. We cannot solve the problems of the next generation and it would be foolish to try, but at any rate it must have no just cause to blame us for the condition in which it receives its heritage.

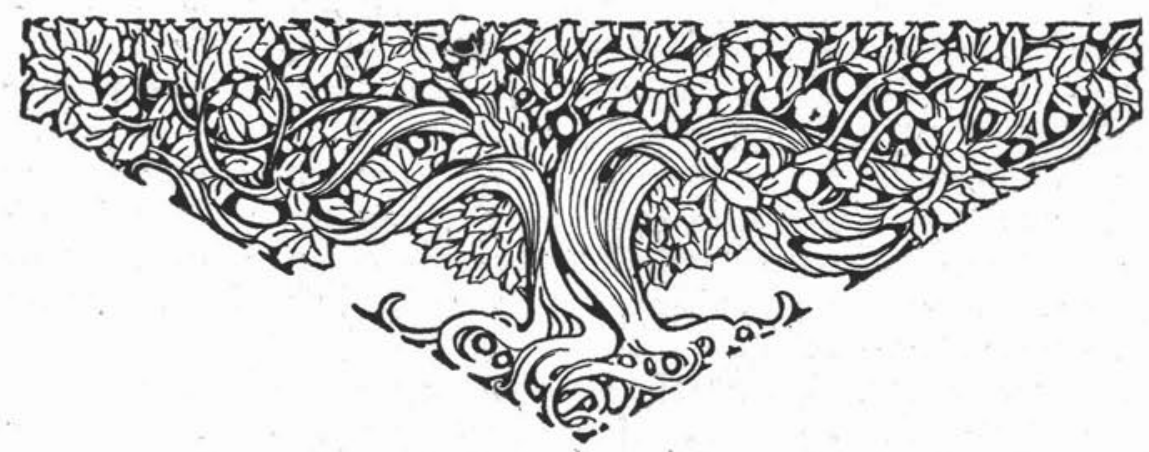

